Research Journal of Pharmacology and Pharmacy
(ISSN:2572-8377)

\title{
PUNICA GRANATUM Vrs COVID - 19 Fruit to Drug
}

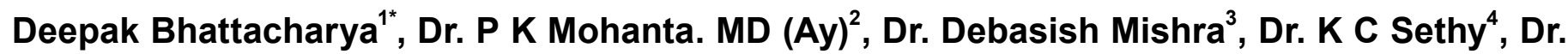
Jyotsana Sharma ${ }^{5}$, Dr. P K Pradhan ${ }^{6}$, Dr. Vahideh Samadiyan ${ }^{7}$, Dr. Mahtab Pouyanfar ${ }^{8}$, Dr. Parisa Mohamadpour ${ }^{9}$, Prof. Ghassem Habibi Bibalani ${ }^{10}$

${ }^{1}$ Research \& Nursing, At Fight-Cancer at Home, Sri Radha Krishna Raas Mandir, Kedar Gouri Road, Bhubaneswar-751002,Odisa, India. ${ }^{2} \mathrm{MD}$ (Ay), Govt Drug Inspector; Registrar Ay Council; Principal. IGMMC \& Hospital, H-2/58,SS Enclave, Khandagiri,Bhubaneswar-751030, Odisa. ${ }^{3}$ MBBS, Director, Model Blood Bank, Capital Hospital (Govt., Apex) - Bhubaneswar, Odisa, India. ${ }^{4}$ LLM, Ph.D, Advocate, District \& Sessions Court, Bhubaneswar, Odisa, India. ${ }^{5}$ Ph.D; Director (Act) \& Principal Scientist (Plant Pathology) ICAR-National Research Centre on Pomegranate, Solapur, Maharastra, India, 413255. 'BAMS, Medical Officer, Indian Red Cross Society Clinic (Ay), Koraput, Odisa, India. ${ }^{7}$ Ph.D, Lecturer, University of Applied Science and Technology, Shahid Sardari Branch, Tabriz, East Azerbaijan. ${ }^{8} \mathrm{Ph} . \mathrm{D}$, Instructor, TVTO-Medicinal Plants, Teheran, Iran. ${ }^{9} \mathrm{Ph} . \mathrm{D}$, Asst Prof. Forest \& Rangeland Research \& Watershed Management Dept; Gilan Agril \& Natural Resources Research \& Edu center; Rasht, Iran. ${ }^{10}$ Department of Natural Resources, Shabestar Branch, Islamic Azad University, Shabestar, Iran

\section{ABSTRACT}

Punica granatum is historically known worldwide as a versatile medicinal fruit. 2 major varieties are presented (i) indo Ayurvedic type (Punica Ayurvedica ?) that is small, harsh and yields no juice and (ii) the juice variety which is commercialised. IndoIranian joint effort presents a tome of textual data pertaining to the medicinal aspects of Punica. Gallagic group. Enantiomers. Antagoniostic. Ayurvedic texts and Occidental research modelled papers in tabulated form chronologically succinctly bringing out the evidence based historiography \& medicocultural heritage. On such platform a range of formulations; fruit-to-finished product are presented for the 1st time machine makeable and very specifically also by hand, at home. Poly pathology spectrum; versatile therapeutic range; medico-legal; lyophilisation; sterilisation; etc. aspects are also indicated. Includes Tablets; Suspensions for General to Geriatric case types. Ground breaking. Frank.

Keywords: Punica Granatum Formulation For Covid; Ellagic acid is Anti-virus; Ellaghitanins; Gallagic group

*Correspondence to Author: Deepak Bhattacharya Research \& Nursing, At Fight-Cancer at Home, Sri Radha Krishna Raas Mandir, Kedar Gouri Road, Bhubaneswar-751002, Odisa, India.

How to cite this article:

Deepak Bhattacharya, P K Mohanta,Debasish Mishra,K C Sethy, Jyotsana Sharma, P K Pradhan, Vahideh Samadiyan, Mahtab Pouyanfar, Parisa Mohamadpour, Ghassem Habibi Bibalani. PUNICA GRANATUM Vrs COVID-19 Fruit to Drug. Research Journal of Pharmacology and Pharmacy, 2020; 4:9.

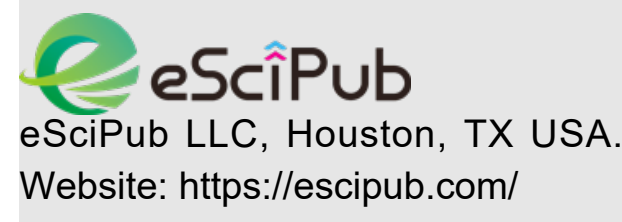




\section{Introduction}

SARS CoV-2 sub-spp., unusually stable virus, causes the efficient contagion Covid-19. Within 120 days it has become pan global pandemic. Either aspects are unheard off with never before like patho-physiology and grave prognosis (fatal outcome). A member of any family getting infected if left untreated demises within 15days. If not effectively quarantined it then leads to all member demise. however well off \& large be that joint family (supporting info). This has wrought dread \& havoc. All out combat with every wherewithal is the way out. There are no alternatives. Historically, in all cultures and civilisation-based schools of medicine the Punica Grantum Linn., has been considered as panacea for many a human pathology ${ }^{[1]}$. India is the largest producer [2]. The Govt of India in all its cumulative wisdom has hence set up 'The National Research Centre

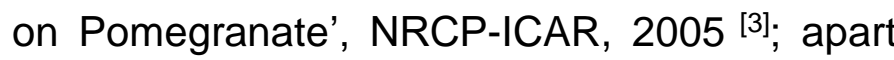
HRC-ICAR ${ }^{[4]}$. Additionally, pan globally there are tomes of individual \& institution driven works ranging the five decades before present which all are herein relied upon. From every perspective Indo \& European literature have been explored well and covers agro-met; cultivars; atypical; etc., perspective (collateral domain). In this communication we present the indo Ayurvedic punica; and also, fleetingly examine Persian literature for topical levity for either have attracted (relatively) less of research focus from caption context. We choose the generic term 'punica' for it encompasses almost all the species \& subspecies of the cultivars, pan global and also address our caption. Interestingly, the Indian civilisation has been in continuum (sans any break) in its present geo-location for at least 5000yrs before present and the 'extraordinary' Ayurvedic punica (our apportioned epitaph) as a textual medicinal member for at least 2500yrs before present. Therefore, we present (as different from 'discuss') the genus Punica as known drug source of choice vis-a-vis COVID-19; the fruit and its parts in various combinations towards formulation and fixed doses (supplements/ prophylactics/ therapeutics including psycho-somatic pseudo supports; etc., any school of health care) so that the stake holders may straight choose pick. Isolation; purifications \& fractions whatever \& however done being covered alike. All stake holders (punica-\&-covid) may find this work as of seminal relevance. Meanwhile, covid caused mortality remains rampant in continuum unabated $24 \times 7$. Our teachers had taught us to 'fight to finish and do a good job'. Gandhian dictum of hand makeable; home makeable is our hidden agenda.

\section{Historiography}

Table-I highlights the prior-art aspects vis-a-vis human maladies, as anti-viricide; anti-malaria; others and as a versatile member in numerous drug discovery matters ${ }^{[5]}$. Few of members of Table-I have also been cited as references.

Table - 1 Indicative Histeriography of Punica in Academic Domain. Caption Context.

\begin{tabular}{|c|c|c|c|c|}
\hline SI No & Year & Conveniently extrited Relevant References. Select. 4 Decades & Remarks & Country \\
\hline 1 & 1982 & $\begin{array}{c}\text { Screening of Iranian plant for antimicrobial activity. Acta Pharamceutica } \\
\text { Suecia 19, 303-308 }\end{array}$ & $\begin{array}{c}\text { Anti-micro- } \\
\text { bial }\end{array}$ & Iran \\
\hline 2 & 1988 & $\begin{array}{c}\text { A study of some properties of pomegranate (Punica granatum) from dif- } \\
\text { ferent localities -FAO, UN. Harana i ishrana, ISSN: 0018-6872. }\end{array}$ & Properties & $\begin{array}{c}\text { Yugo- } \\
\text { slavia, }\end{array}$ \\
\hline 3 & 1995 & $\begin{array}{c}\text { Antiviral activity of tannin from the pericarp of Punicagranatum L. } \\
\text { against genital Herpes simplex virus in vitro. Chung Kuo Chung YaoTsa } \\
\text { Chin20, 556-558 }\end{array}$ & $\begin{array}{c}\text { Anti } \\
\text { Virus }\end{array}$ & China \\
\hline 4 & 1997 & $\begin{array}{c}\text { Polyphenols of pomegranate peels show marked anti-tumor and anti-vi- } \\
\text { ral action. Chemistry of Natural Compounds vol.33, pp.98-99 }\end{array}$ & Anti Tumor & $\begin{array}{c}\text { Uzbeki- } \\
\text { stan }\end{array}$ \\
\hline 6 & 1997 & $\begin{array}{c}\text { Tannins from the leafs of Punica Granatum, Phytochemistry, Vol-48, } \\
\text { pp.819. }\end{array}$ & Property & India \\
\hline 4 & 1998 & $\begin{array}{c}\text { Pomegranate: a role in health promotion and AIDS? In: Watson RR, Nu- } \\
\text { trition, Foods and AIDS, eds. CRC Press, Boca Raton, Florida, USA, pp } \\
179-192\end{array}$ & AIDS & USA \\
\hline
\end{tabular}

RJPP: https://escipub.com/research-journal-of-pharmacology-and-pharmacy/ 


\begin{tabular}{|c|c|c|c|c|}
\hline 7 & 1998 & $\begin{array}{l}\text { Antiviral or antifungal composition comprising an extract of pomegranate } \\
\text { rind or other plants and method of use. US Patent. } 5,840,308\end{array}$ & $\begin{array}{l}\text { Anti-virus \& } \\
\text { Anti-fungal }\end{array}$ & USA \\
\hline 8 & 1990 & $\begin{array}{c}\text { Compendium of Indian Medicinal Plants: Central Drug Research Labor- } \\
\text { atory, CSIR, Lko, [1999 - 95], Vol - 1, 1990, p. 335, Vol - 2, 1993, } \\
\text { p.573, Vol - IV, p. 611, Vol -5, p. 709. (preceded by Glossary AND } \\
\text { earlier by RRL Bhubaneswar publication - } 3 \text { Vols) }\end{array}$ & Properties & India \\
\hline 9 & 2000 & $\begin{array}{c}\text { news.bbc.co.uk/2/hi/south_asia/988316.stm } \\
\text { Tuesday, } 24 \text { October, 2000, 12:16 GMT 13:16 UK. India claims herbal } \\
\text { malaria cure }\end{array}$ & Anti-Malaria & $\begin{array}{l}\text { BBC } \\
\text { (India) }\end{array}$ \\
\hline 10 & 2000 & $\begin{array}{c}\text { Why a pomegranate? } \quad \text { British Medical Journal } \\
\text { 2000; } 321 \text { doi: } \text { https://doi.org/10.1136/bmj.321.7269.1153 }\end{array}$ & Tonic & London \\
\hline 11 & 2001 & $\begin{array}{l}\text { Immunomodulatory activity of Punica granatum in rabbits--a preliminary } \\
\text { study. } \\
\text { Journal of Ethnopharmacol } 2001,78: 85-87 .\end{array}$ & Immunity & $\begin{array}{l}\text { USA - } \\
\text { NRI }\end{array}$ \\
\hline 12 & 2003 & $\begin{array}{c}\text { A mixed Herbo-Chem-Anti-Malarial: Indicates cure \& prophylaxis } \\
\text { against Pf \& Pv; }>500 \text { cases in } 5 \text { yrs; empirical basis of holistic ap- } \\
\text { proach. } A J T M H, 69,484 .\end{array}$ & Anti-Malaria & India \\
\hline 13 & 2004 & $\begin{array}{c}\text { GrGranatum's Dermis indicates Prophylaxis against Malaria \& wide spec- } \\
\text { trum anti-viral property in Human use. American Journal of Tropical } \\
\text { Medicine \& Hygiene, Oct. 2004, Abstract No.968, 171(4), 288.m } \\
\text { http://www.ajtmh.org/content/71/4 suppl/225.full.pdf+html }\end{array}$ & -Do- & India \\
\hline 14 & 2004 & $\begin{array}{c}\text { Punica granatum (Pomegranate) juice provides an HIV-1 entry inhibitor } \\
\text { and candidate topical microbicide. BMC Infect Dis, } 4,41 . \\
\text { https://doi.org/10.1186/1471-2334-4-41 }\end{array}$ & HIV & $\begin{array}{l}\text { USA - } \\
\text { NRI }\end{array}$ \\
\hline 15 & 2005 & $\begin{array}{l}\text { Punicagranatum (Pomegranate) juice provides an HIV-1 entry inhibitor } \\
\text { and candidate topical microbicide. In: Annals of the New York Academy } \\
\text { of Sciences (New York academy of sciences) pp. 311-27. }\end{array}$ & -Do- & USA \\
\hline 16 & 2005 & $\begin{array}{l}\text { Rapid large-scale purification of ellagitannins from pomegranate husk, a } \\
\text { by-product of the commercial juice industry. Separation and Purification } \\
\text { Technology, 41, 49-55. }\end{array}$ & Purification & USA \\
\hline 17 & 2005 & $\begin{array}{l}\text { National Research Centre on Pomegranate, Indian Council of Agricul- } \\
\text { tural Research, Soalapur, PIN-413 255, India. ESTABLISHED by Govt } \\
\text { Of India. }\end{array}$ & $\begin{array}{l}\text { Exclusive } \\
\text { Research } \\
\text { Institute }\end{array}$ & $\begin{array}{l}\text { Public } \\
\text { Institu- } \\
\text { tion }\end{array}$ \\
\hline 18 & 2006 & $\begin{array}{c}\text { Pomegranate juice ellagitannin metabolites are present in human } \\
\text { plasma and some persist in urine for up to } 48 \text { hours. The Journal of } \mathrm{Nu} \text { - } \\
\text { trition, } 136,2481-2485 .\end{array}$ & $\begin{array}{l}\text { In-Blood } \\
\text { Life }\end{array}$ & USA \\
\hline 19 & 2006 & $\begin{array}{l}\text { Pomegranates: Ancient Roots to Modern Medicine. } \\
\text { CRC Press Taylor and Francis Group, FL. 244p }\end{array}$ & $\begin{array}{l}\text { Historiog- } \\
\text { raphy }\end{array}$ & USA \\
\hline 20 & 2007 & $\begin{array}{l}\text { Antioxidant, antimalarial and antimicrobial activities of tannin-rich frac- } \\
\text { tions, ellagitannins and phenolic acids from Punica granatum L. Planta } \\
\qquad \text { Medica, 73, 461-467. USA }\end{array}$ & Anti-oxidant & Do NRI \\
\hline 21 & 2008 & $\begin{array}{l}\text { Anthocyanins characterization of } 15 \text { Iranian pomegranate (Punica gran- } \\
\text { atum L.) varieties and their variation after cold storage and pasteuriza- } \\
\text { tion. Eur Food Res Technol } 227,881-887 \text {. } \\
\text { https://doi.org/10.1007/s00217-007-0799-1. }\end{array}$ & Storing & Iran \\
\hline 22 & 2008 & $\begin{array}{l}\text { Therapeutic applications of pomegranate (Punica granatum L.): A Re- } \\
\text { view. } \\
\qquad \begin{array}{l}\text { Altern Med Rev 2008, 13:128-144. }\end{array}\end{array}$ & $\begin{array}{l}\text { Therapeutic } \\
\text { Properties }\end{array}$ & USA \\
\hline 24 & 2009 & Journal of Ethnopharmacology, Vol. 125, No. 2, 2009, pp. 279-285. & Anti-Malaria & Italy \\
\hline 25 & 2010 & $\begin{array}{l}\text { Elagitannins of the fruit rind of pomegranate (Punica granatum) antago- } \\
\text { nize in vitro the host inflammatory response mechanisms involved in the } \\
\text { onset of malaria, Malaria Journal, 9:208 }\end{array}$ & - Do- & Do \\
\hline 26 & 2010 & $\begin{array}{l}\text { Pomegranate phytochemicals: Nutraceutical and Therapeutic values. In: } \\
\text { Fruit, Vegetable, Cereal science and Biotechnology } \mathbf{4} \text { (special issue 2), }\end{array}$ & $\begin{array}{l}\text { Nutraceuti- } \\
\text { cals }\end{array}$ & Japan \\
\hline
\end{tabular}

RJPP: https://escipub.com/research-journal-of-pharmacology-and-pharmacy/ 


\begin{tabular}{|c|c|c|c|c|}
\hline & & $\begin{array}{c}\text { Global Science Books (publ.), pp. 56. http://www.globalscience- } \\
\text { books.info/Online/GSBOnline/im- } \\
\text { ages/2010/FVCSB 4(SI2)/FVCSB 4(SI2)56-76o.pdf }\end{array}$ & & \\
\hline 27 & 2010 & $\begin{array}{c}\text { Pomegranate Breeding. In: Fruit, Vegetable, Cereal science and Bio- } \\
\text { technology } 4 \text { (Spl issue 2), Global Science Books (publ.), pp26- } \\
\text { http://www.globalsciencebooks.info/Online/GSBOnline/im- } \\
\text { ages/2010/FVCSB_4(SI2)/FVCSB_4(SI2)26-34o.pdf }\end{array}$ & Breeding & Do \\
\hline 28 & 2010 & $\begin{array}{l}\text { Global Scenario of Pomegranate (Punicagranatum L) Culture with Spe- } \\
\text { cial Reference to India. In: Fruit, Vegetable, Cereal science and Biotech- } \\
\text { nology, } 4 \text { (special issue 2), Global Science Books (publ.), pp 07-18. } \\
\text { http://www.globalsciencebooks.info/Online/GSBOnline/im- } \\
\frac{\text { ages/2010/FVCSB 4(SI2)/FVCSB 4(SI2)7-180.pdf http://www.glob- }}{\text { alsciencebooks.info/Journals/images/FVCSBDescripStyle.pdf }}\end{array}$ & $\begin{array}{l}\text { Agril-Re- } \\
\text { view }\end{array}$ & Do \\
\hline 29 & 2010 & $\begin{array}{l}\text { Origin, History and Domestication of Pomegranate. In: Chandra R (Ed) } \\
\text { Pomegranate. Fruit, Vegetable and Cereal Science and Biotechnology } 4 \\
\text { (Special Issue 2), pp. 1-6. NRCP, http://nrcpomegranate.org/ }\end{array}$ & $\begin{array}{l}\text { Historio- } \\
\text { graphy }\end{array}$ & India \\
\hline 30 & 2011 & $\begin{array}{c}\text { "Fight Malaria at Home: Therapeutic \& Prophylaxis Clinical Data," Asian } \\
\text { Pacific Journal of Tropical Disease, Vol. 1, No. 2, pp. 142-149. }\end{array}$ & Anti-Malaria & India \\
\hline 31 & 2012 & In Infectious Diseases, Vol. 2, pp.13-18. doi:10.4236/aid.2012.21003. & $\begin{array}{l}\text { Anti-Inflam- } \\
\text { mation }\end{array}$ & India \\
\hline 32 & 2012 & $\begin{array}{c}\text { International Journal of Clinical Medicine, 2012;3(1):1-8. } \\
\text { Doi:10.4236/ijcm. 2012.31001. }\end{array}$ & -Do- & Gabon \\
\hline 33 & 2014 & $\begin{array}{l}\text { Fruit rots of pomegranate (cv. Wonderful) in Greece, Australasian Plant } \\
\text { Pathology 43(5):583-588. DOI: } 10.1007 / \mathrm{s} 13313-014-0300-0\end{array}$ & $\begin{array}{l}\text { Fruit Pathol- } \\
\quad \text { ogy }\end{array}$ & Greece \\
\hline 34 & 2014 & $\begin{array}{l}\text { The effect of technological treatments of the pasteurized juice pro- } \\
\text { cessing on the antioxidant compounds content and the antioxidant activ- } \\
\text { ity of pomegranate (Punicagranatum L.) fruits juice. Middle East Journal } \\
\text { of Applied Sciences 4(2), 232-http://www.curre- } \\
\text { sweb.com/mejas/mejas/2014/232-242.pdf }\end{array}$ & Pasteur & India \\
\hline 35 & 2104 & $\begin{array}{l}\text { Anti-obesity effects of Taif and Egyptian pomegranates: molecular } \\
\text { study. Biochemistry \& Molecular Biology, } \\
\text { https://doi.org/10.1080/09168451.2014.982505 }\end{array}$ & Anti-Obesity & $\begin{array}{c}\text { Saudi \& } \\
\text { Egypt }\end{array}$ \\
\hline 36 & 2015 & $\begin{array}{l}\text { Evaluation of Egyptian pomegranate cultivars for antioxidant activity, } \\
\text { phenolic and flavonoid contents, 2015. Egyptian Pharmaceutical Jour- } \\
\text { nal, Volume: } 15 \text { | Issue: } 3 \text { | Page: } 143-149\end{array}$ & $\begin{array}{l}\text { Anti-Oxi- } \\
\text { dant }\end{array}$ & Egypt \\
\hline 37 & 2016 & $\begin{array}{l}\text { Biochemical diversity in wild and cultivated pomegranate (Punica gran- } \\
\text { atum L.) in Pakistan, The Journal of Horticultural Science and Biotech- } \\
\text { nology, 92:2, 199-205, DOI: } 10.1080 / 14620316.2016 .1252250\end{array}$ & Biodiversity & Pakistan \\
\hline 38 & 2016 & $\begin{array}{l}\text { Effects of supplementation with pomegranate juice on plasma C-reac- } \\
\text { tive protein concentrations: A systematic review \& meta-analysis of ran- } \\
\text { domized controlled trials, Phytomedicine 15;23(11):1095-102. doi: } \\
\text { 10.1016/j.phymed.2015.12.008. Epub 2015 Dec 30. }\end{array}$ & $\begin{array}{l}\text { C Reactive } \\
\text { Protein }\end{array}$ & $\begin{array}{l}\text { Roma- } \\
\text { nia \& } \\
\text { Aus- } \\
\text { tralia }\end{array}$ \\
\hline 39 & 2017 & $\begin{array}{c}\text { Ghare Maro Malaria Social Service to Drug Discovery - Bottom Up } \\
\text { Model: A Review. Air Water Borne Diseases, 6: 135. doi: 10.4172/2167- } \\
7719.1000135\end{array}$ & $\begin{array}{l}\text { Red Cross } \\
\text { Service }\end{array}$ & India \\
\hline 40 & 2017 & $\begin{array}{c}\text { Pomegranate (Punica Granatum L.) Peel Hydroalcoholic Extract Sup- } \\
\text { plementation Reduces Pain and Improves Clinical Symptoms of Knee } \\
\text { Osteoarthritis: A Randomized Double-Blind Placebo Controlled Study, } \\
\text { Iranian Red Crescent Medical Journal, 19(1): } \\
\text { e38577. doi:10.5812/ircmj.38577. }\end{array}$ & $\begin{array}{l}\text { Analgesic \& } \\
\text { anti-Arthritis }\end{array}$ & Iran \\
\hline 41 & 2017 & $\begin{array}{c}\text { Pomegranate ellagitannins stimulate the growth of Akkermansia mucini- } \\
\text { phila in vivo, Anaerobe., Feb;43:56-60. doi: } 10.1016 / \text { j.anaer- } \\
\text { obe.2016.12.003. Epub 2016 Dec } 7 .\end{array}$ & Gut Flora & USA \\
\hline
\end{tabular}

RJPP: https://escipub.com/research-journal-of-pharmacology-and-pharmacy/ 


\begin{tabular}{|c|c|c|c|c|}
\hline 42 & 2017 & $\begin{array}{l}\text { Screening of genetic diversity in pomegranate (Punica granatum L.) cul- } \\
\text { tivars from Egypt and Kingdom of Saudi Arabia (KSA), 2017. Bioscience } \\
\text { Research, 14(4):887-894 }\end{array}$ & ?? & $\begin{array}{l}\text { Saudi } \\
\text { Arabia }\end{array}$ \\
\hline 43 & 2017 & $\begin{array}{l}\text { Effect of extraction method and thermal processing on retention of bio- } \\
\text { acvtive compounds of pomegrante (Punicagranatum) (cv. Bhagwa) } \\
\text { juice. Indian Journal of Agricultural Sciences, } 87 \text { (11), 1445-52, } \\
\text { https://www.researchgate.net/publication/321050781_ }\end{array}$ & $\begin{array}{l}\text { Extraction } \\
\text { Method }\end{array}$ & India \\
\hline 44 & 2018 & $\begin{array}{l}\text { Physico-chemical characteristics of pomegranate accessions from the } \\
\text { Kurdistan region, Iraq. Physiology and Biology Of Medicinal Plants, } \\
\underline{10.2298 / \mathrm{JAS} 1804355 \mathrm{M}}\end{array}$ & Character & Iraq \\
\hline 45 & 2018 & $\begin{array}{c}\text { Vasculoprotective Effects of Pomegranate (Punica granatum L.) Fron- } \\
\text { tiers in Pharmacology, REVIEW ARTICLE, } \\
\text { https://doi.org/10.3389/fphar.2018.00544 }\end{array}$ & $\begin{array}{l}\text { Blood Ves- } \\
\quad \text { sel } \\
\text { Protection }\end{array}$ & $\begin{array}{l}\text { Ger- } \\
\text { many }\end{array}$ \\
\hline 46 & 2018 & $\begin{array}{l}\text { A study on physical properties of pomegranate (Punica granatum L., } \\
\text { Punicaceae) fruits, Japan, DOI: 10.13140/RG.2.2.32554.67527 }\end{array}$ & $\begin{array}{l}\text { Physical } \\
\text { Properties }\end{array}$ & Japan \\
\hline 47 & 2018 & $\begin{array}{l}\text { Trokhymchuk T. Yu., et.al., 2018. Anti-HIV activity of ellagitannins from } \\
\text { alder tree fruits, Biopolymers and Cell 34(3):218-228, DOI: } \\
10.7124 / \mathrm{bc} .00097 \mathrm{C}\end{array}$ & Anti-HIV & Ukraine \\
\hline 48 & 2018 & $\begin{array}{l}\text { Punica granatum (Pomegranate) activity in health promotion and cancer } \\
\text { prevention, Oncology Review. 12(1): pp.345.doi: } \underline{10.4081 / o n-} \\
\text { col.2018.345 PMCID: PMC5806496. PMID: } \underline{29441150}\end{array}$ & Anti-Cancer & Iran \\
\hline 49 & 2019. & $\begin{array}{l}\text { Pomegranate genetic resources and their utilization in China, Acta Hortic. 1254, } \\
\text { 49-56. DOI:10.17660/ActaHortic.2019.1254.8, } \\
\text { https://doi.org/10.17660/ActaHortic.2019.1254.8 }\end{array}$ & Horticulture & China \\
\hline 50 & 2019 & $\begin{array}{c}\text { Primary Metabolites, Anthocyanins, and Hydrolyzable Tannins in the } \\
\text { Pomegranate Fruit, Frontiers in Plant Sci., } 17 \text { May } 2019 \text { | REVIEW AR- } \\
\text { TICLE, https://doi.org/10.3389/fpls.2019.00620 }\end{array}$ & Character & Israel \\
\hline 51 & 2019 & $\begin{array}{l}\text { Department of Agriculture, Cooperation \& Farmers Welfare, } \\
\text { GOI.http://agricoop.gov.in/sites/default/files/DATA-2018- } \\
\text { 19\%20\%283rd\%20Adv.Est .\%29\%20-\%20Website.pdf }\end{array}$ & $\begin{array}{l}\text { Farming \& } \\
\text { Farmers }\end{array}$ & India \\
\hline 52 & 2019 & $\begin{array}{l}\text { Targeted metabolite profiling to gain chemometric insight into In- } \\
\text { dian pomegranate cultivars and elite germplasm. Journal of Science of } \\
\text { Food and Agriculture (wileyonlinelibrary.com) DOI 10.1002/jsfa.9751) }\end{array}$ & $\begin{array}{l}\text { Math \& sta- } \\
\text { tistical } \\
\text { methods }\end{array}$ & India \\
\hline 54 & 2019 & $\begin{array}{c}\text { Anti-Influenza Virus Activity and Phenolic Content of Pomegranate } \\
\text { (Punicagranatum L.) Peel Extract and Fractions. Avicenna Journal of } \\
\text { Medical Biotechnology,11(4), 285-291. } \\
\text { https://www.ncbi.nlm.nih.gov/pmc/articles/PMC6925405/ }\end{array}$ & Anti-Virus & Iran \\
\hline 55 & 2020 & $\begin{array}{c}\text { https://figshare.com/account/login; } \\
\text { Please Login with this: oddisilab1@dataone.in Password: Kedar- } \\
\text { Gouri123* }\end{array}$ & $\begin{array}{l}\text { Anti-SARS; } \\
\text { Anti-Covid }\end{array}$ & India \\
\hline \multicolumn{5}{|c|}{$\begin{array}{l}\text { www: Our search indicates an interesting histology about the scholarly efforts using the Punica fruit \& its dermis. } \\
\text { Numerous studies commence post SI. No.9. }\end{array}$} \\
\hline \multicolumn{5}{|c|}{$\begin{array}{l}\text { Note: Indian ayurvedic Punica is quite different on pan global basis. } \\
\text { It is entirely medicinal (only for medicine moiety). } \\
\text { Indian Ayurveda uses only the rind of such atypical (only for medicine). Others use the juice. }\end{array}$} \\
\hline \multicolumn{5}{|c|}{$\begin{array}{l}\text { Reuters News Media Inc., 1996. Pomegranates could help in battle against AIDS. March 10 } \\
\text { gis.com/news/re/1996/RE960310.html NOT AVAILABLE }\end{array}$} \\
\hline
\end{tabular}

\section{Discussion - Table - I}

Table-1 spans the period of $1975-2020$ and the global geo space. Southern hemisphere is conspicuous by absence does not mean that punica does not grow there or anything alike. Evidence based occidental model of study appa- rently commences with anti-microbe efficacy. Ref No. ${ }^{[6]}$ published by the Indian National Science Academy presents a select list of indo Ayurvedic treatises in vernacular (Odia lingua \& script; Sanskrit lingua \& Devanagari script) in Palm Leaf form of great antiquity \& authority 
about which consciousness is almost nil. Each refer to the punica. Thus, we may aver that other cultural regions (all nations) may be having other tomes as well. Efforts are scant. However, the rindlcarp of the indo ayurvedic member (Fig-1 \& 2) has not been used to combat virus until year 2004, Table-I. Also, did not use the same as antimalarial. We present a few formulations and fixed dose orals. Any sub spp., can be used.

In India the pomegranate occupies 2.62 lakh hectares; annual production of 3.03 million (50\% of the global production; $2^{\text {nd }}$ being China). Suggests a triangular nexus between census and fruit grown \& consumption. Proposes historical \& cultural factors apart public money focus during India plan periods. ICAR-NRCP, India is said to have the largest stockpile of Punica related wherewithal for ready deployment. The India $\mathrm{Na}$ tional Germplasm Repository of ICAR-NRCP has a collection of 376 germplasm; 222 exotic germplasm collected from other countries; 140 indigenous including 87 wild types, 55 cultivated/ local cultivars and addition 12 promising hybrid lines (Personal communication from ICAR) ${ }^{[7]}$. Moot point is that the member as in Fig- 1 \& 2 suggests to be neither a wild nor an albino [T-I, SI No.30]. Moreover, it is anti-toxin (supporting info; see Ref No.19). Statistical method indicates that punica begs inquest and indo ayurvedic variety the more.

\section{Persian Sources:}

Health care has always been technical. Ancient \& medieval India had a long period of technocultural exchanges with Persia ${ }^{[8,9]}$. Table-II provides the Persian sources \& details thereof along with indications. It bares select Historical treatise and is non-exhaustive.

Table - II

\begin{tabular}{|l|c|c|}
\hline \multicolumn{1}{|c|}{ Mention of Pomegranate in Persian Works } & Covenance & SI No. \\
\hline $\begin{array}{l}\text { Eat sweet and sour pomegranate, because it strengthens man and revives } \\
\text { the blood. }\end{array}$ & $\begin{array}{c}\text { Amjadi et al., 2016 } \\
\text { Imam Reza (AS) }\end{array}$ & $\mathbf{1}$ \\
\hline $\begin{array}{l}\text { Eat pomegranate with the part where the seeds are located, because it } \\
\text { cleanses the stomach, and any pomegranate seed, when placed in the } \\
\text { stomach, will bring the heart to life and enlighten the soul \& eliminate the } \\
\text { temptation of the devil for forty days. Imam Sadegh (AS) }\end{array}$ & $\begin{array}{c}\text { Amjadi et al., 2016 } \\
\text { Mohaddese Nouriet al., } \\
1987\end{array}$ & $\mathbf{2}$ \\
\hline $\begin{array}{l}\text { Antioxidant; Lowering blood pressure; Improving vascular function } \\
\text { Lowering blood pressure in people with high blood pressure }\end{array}$ & $\begin{array}{c}\text { Asgary et al., 2015 } \\
\text { Avicenna, 2005 }\end{array}$ & $\mathbf{3}$ \\
\hline $\begin{array}{l}\text { its compounds, Ellagitannins, Galoutanins, Anthocyanins, Flavonoids, Ster- } \\
\text { ols, Terpenoids, Tannin, Polyphenols, Alkaloids, Organic Acids, B1, B2, C } \\
\text { vitamins can be mentioned. }\end{array}$ & $\begin{array}{c}\text { Bayati and Asadi-Gharneh, } \\
2019\end{array}$ & $\mathbf{4}$ \\
\hline Antioxidant activity of pomegranate seed oil & Dadashi et al., 2013 & $\mathbf{5}$ \\
\hline $\begin{array}{l}\text { Antibacterial } \\
\text { Prevention of heart disease; Liver fibrosis; Anticancer; Antibacterial; Anti- } \\
\text { fungal }\end{array}$ & Dadgar et al., 2007 & $\mathbf{6}$ \\
\hline $\begin{array}{l}\text { Stopping tumor growth and regulating the growth of tumor growth-sup- } \\
\text { pressing proteins in the prevention of cancers Controlling the enzymes in- } \\
\text { volved in the synthesis of fats and increasing the synthesis and secretion } \\
\text { of insulin from pancreatic beta cells and increasing their sensitivity are the } \\
\text { most important mechanisms for reducing fat and blood sugar }\end{array}$ & Khajebishaket al., 2015 & $\mathbf{7}$ \\
\hline $\begin{array}{l}\text { Pomegranate cleanses the blood, opens the blood vessels of the body and } \\
\text { the abdomen, and Strengthens the liver. Pomegranate is good for jaundice, } \\
\text { heart palpitations and acute cough. It smoothes the sound and refreshes } \\
\text { the face. It hydrates the body and kills stomach worms. } \\
\text { Imam Reza (AS) }\end{array}$ & Mahmoudi, 2011 & $\mathbf{8}$ \\
\hline $\begin{array}{l}\text { Eat pomegranates, every pomegranate seed that is placed in the stomach } \\
\text { will brighten the heart and lullaby or stay away from the devil for forty days. } \\
\text { Imam Reza (AS) }\end{array}$ & $\begin{array}{c}\text { Mohaddese Nouriet al., } \\
\text { Horre Ameli, 1971 }\end{array}$ & $\mathbf{1 0}$ \\
\hline
\end{tabular}

RJPP: https://escipub.com/research-journal-of-pharmacology-and-pharmacy/ 


\begin{tabular}{|c|c|c|}
\hline Eat pomegranate to keep your mouth clean and fragrant. Imam Reza (AS) & $\begin{array}{l}\text { Mahmoudi, } 2011 \\
\text { Momen Tonkaboni et al., } \\
2007\end{array}$ & 11 \\
\hline $\begin{array}{l}\text { Whenever the Messenger of God (PBUH) said a pomegranate, he would } \\
\text { not share it with anyone, and he would say that in each pomegranate there } \\
\text { is one seed of heavenly seeds. } \\
\text { Imam Reza (AS) }\end{array}$ & $\begin{array}{l}\text { Mahmoudi, } 2011 \\
\text { HorreAmeli, } 1971\end{array}$ & 12 \\
\hline Pomegranate makes the child beautiful. Imam Reza (AS) & $\begin{array}{l}\text { Mahmoudi, } 2011 \\
\text { Momen Tonkaboni et al., } \\
2007\end{array}$ & 13 \\
\hline Pomegranate smoke removes insects and destroys them. Imam Reza (AS) & $\begin{array}{c}\text { Mahmoudi, } 2011 \\
\text { Moaffage Hearviet al., } 2010 \\
\end{array}$ & 14 \\
\hline $\begin{array}{l}\text { Everyone who eats a pomegranate while sleeping will be safe from their } \\
\text { ego until morning. } \\
\text { Imam Sadegh (AS) }\end{array}$ & $\begin{array}{l}\text { Mahmoudi, } 2011 \\
\text { Horre Ameli, } 1971\end{array}$ & 15 \\
\hline $\begin{array}{l}\text { Antioxidants; Treatment of urinary tract infections, lowering blood sugar and } \\
\text { diabetes, psoriasis, hemorrhoids, high blood pressure and atherosclerosis; } \\
\text { Treatment of cardiovascular disease, obesity and high blood pressure; } \\
\text { Treatment of acidosis, infectious diarrhea, microbial infections, intestinal } \\
\text { worms, bleeding and respiratory diseases. Pomegranate flowers in the } \\
\text { treatment of diabetes and asthma, stop bleeding and anti-diabetic drug } \\
\text { Among uterine infections, mastitis, acne, dysentery and oral inflammation. }\end{array}$ & Mazanderany et al., 2014 & 16 \\
\hline $\begin{array}{l}\text { In the juice of the fruit and seeds of this plant, strong and active antioxi- } \\
\text { dants. }\end{array}$ & Mirjalili et al., 2019 & 17 \\
\hline $\begin{array}{l}\text { Different parts of pomegranate include leaves, pods, roots, fruit pods, pom- } \\
\text { egranate juice and its seeds, all of which are effective compounds that can } \\
\text { not only increase the antimicrobial properties, but also the activity of antia. } \\
\text { Antifungal properties }\end{array}$ & Salahvarzi et al., 2011 & 18 \\
\hline 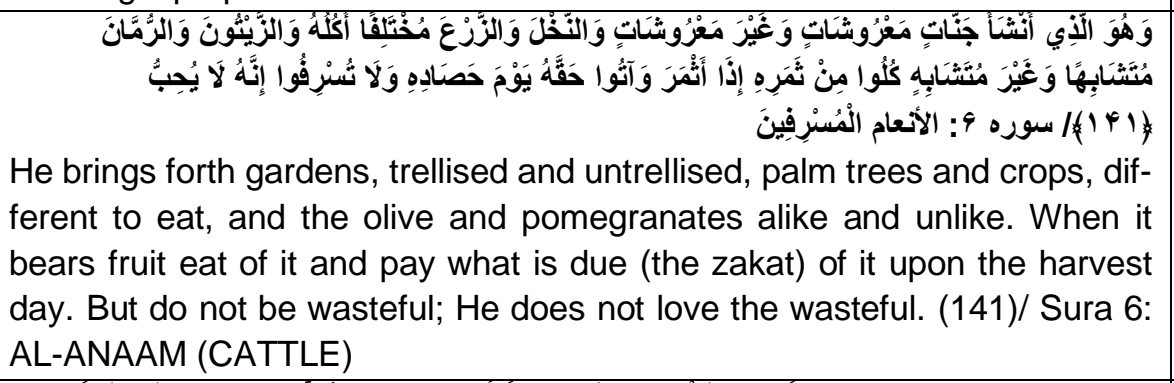 & Shirazi, 1995 & 19 \\
\hline 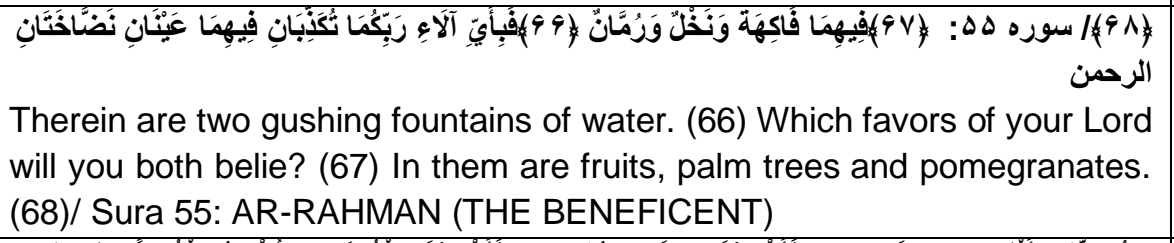 & Shirazi, 1995 & 20 \\
\hline 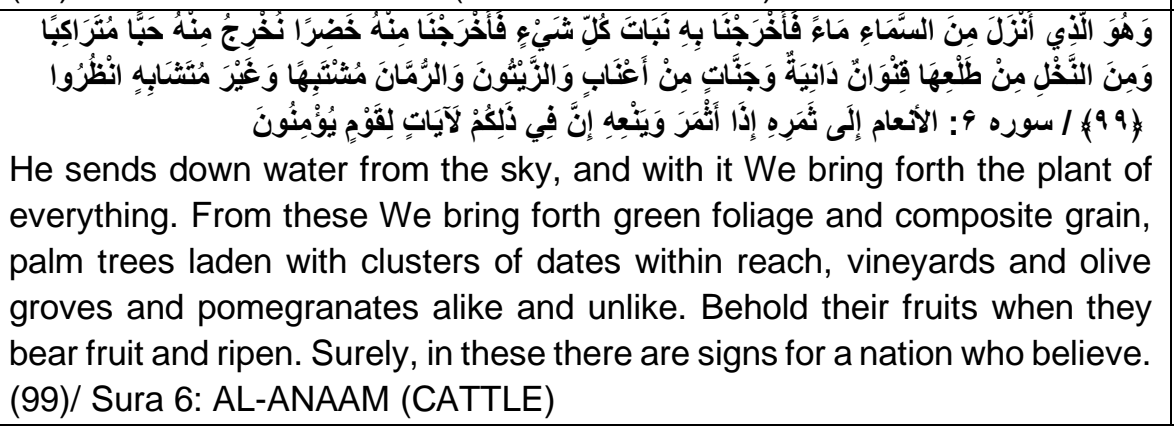 & Shirazi, 1995 & 21 \\
\hline
\end{tabular}

NOTE: Arabic script \& lines to be read from right to left; Table II.

Discussion Table - II:

We can see that fruit pomegranate has been the cynosure of the scribes from historical Persian -to- present Iran in vernacular. As compared

RJPP: https://escipub.com/research-journal-of-pharmacology-and-pharmacy/ 
to the works in Table I \& III the works herein commences from 1987 (SI.2).
Table III presents in brief modern evidence based Iranian research works.

\section{Table - III}

\begin{tabular}{|c|c|c|}
\hline SI. No. & $\begin{array}{l}\text { Modern Period, Evidence Method Research Work References; Iranian. } \\
\text { (read with Table-I \& end References) }\end{array}$ & Year \\
\hline 1 & $\begin{array}{c}\text { Horre Ameli MH. (1971) Vasaelolshiye.Vol 25, bande } 31511 . \\
\text { Beiyrut: Moasese Ahlebeyt; } 1725-1644.158 .\end{array}$ & 1971 \\
\hline 2 & $\begin{array}{c}\text { Mohaddese Nouri H. Mostadrekol Vasaelva Mostanbetol Masael. Vol 13; bande 14829. Qom: } \\
\text { Moasese Ahlebeyt; Chapter 1. 1987. p. 83. }\end{array}$ & 1987 \\
\hline 3 & Shirazi M. Tafsire Nemune. Vol 5. Chape I. Tehran: Darolketab Eslami; 1995. p. 66-68. & 1995 \\
\hline 4 & Avicenna. Ghanoun Fi Alteb (Cannon of Medicine). Beiyrut: Aalamy Publications; 2005. p. 2. & 2005 \\
\hline 5 & $\begin{array}{l}\text { Dadgar, T., Ghaemi, E., Asmar, M., Mazandarani, M., Bazueri, M. (2007). Antibacterial activi- } \\
\text { ties of six medicinal plants against methicillin-resistant and sensitive Staphylococcus au- } \\
\text { reus. } \\
\text { Iranian Journal of Medicinal and Aromatic Plants Research, 23(1), 73-85. }\end{array}$ & 2007 \\
\hline 6 & $\begin{array}{l}\text { Momen Tonkaboni SM. Tohaf Al-Momenin. Edited by Rahimi R, Shams Ardekani MR, Farjad- } \\
\text { mand F. Tehran: Shahid Beheshti University of Medical Sciences, } 2007 .\end{array}$ & 2007 \\
\hline 7 & MoaffageHearvi A. Al-Abnieh An-Hadayegh Al-Advieh. Tehran: Tehran University; 2010. & 2010 \\
\hline 8 & $\begin{array}{l}\text { Mahmoudi, Jalal. 2011. A new review to medicinal plants (fruits and vegetables). } \\
\text { Carpi Publications. } 431 \text { pages. }\end{array}$ & 2011 \\
\hline 9 & $\begin{array}{l}\text { Salahvarzi, Y., Tehranifar, A., Jahanbakhsh, V. (2011). Relation of antioxidant and antifungal } \\
\text { activity of different parts of Pomegranate (Punica granatum L.) extracts with its phenolic con- } \\
\text { tent. Iranian Journal of Medicinal and Aromatic Plants Research, 27(1), 47-56. doi: } \\
10.22092 / \text { ijmapr.2011.6562 }\end{array}$ & 2011 \\
\hline 10 & $\begin{array}{c}\text { Dadashi, S., Mousazadeh, M., Mousavi, S., Yavari, A. (2013). Study on quality properties and } \\
\text { antioxidant activity of the pomegranate seeds of some Iranian commercial varieties. Iranian } \\
\text { Journal of Medicinal and Aromatic Plants Research, 29(2), 502-515. doi: } \\
\text { 10.22092/ijmapr.2013.2871 }\end{array}$ & 2013 \\
\hline 11 & $\begin{array}{l}\text { Mazanderany, M., Ghaemi, E., Bayat, H. (2014). Atecology, Antioxidan if part of Punicagran- } \\
\text { atum var. spinosa. Eco-phytochemical Journal of Medicinal Plants, 2(1), 52-59. }\end{array}$ & 2014 \\
\hline 12 & $\begin{array}{l}\text { Khajebishak Y, Payahoo L. Pomegranate: Its health effects from the Holy Quran and nutrition } \\
\text { science view. jiitm. } 2015 ; 5(4): 310-323\end{array}$ & 2015 \\
\hline 13 & $\begin{array}{l}\text { Asgary, S., Afshani, M., Rafieian-Kopaei, M., Keshvari, M. (2015). Clinical investigation of } \\
\text { blood pressure lowering, endothelial function improving and hypolipidemic of pomegranate } \\
\text { juice in hypertensive subjects. Iranian Journal of Medicinal and Aromatic Plants Research, } \\
\text { 31(3), 418-427. doi: 10.22092/ijmapr.2015.101874 }\end{array}$ & 2015 \\
\hline 14 & $\begin{array}{c}\text { Amjadi O, Mousavi T, Rafiei A, Afzali M A, Yousefpour M, Ghaemi A. 2016. Therapeutic and } \\
\text { Nutritional Effects of Pomegranate from the Perspective of Islamic Texts, Traditional and } \\
\text { Modern Medicine. J Mazandaran Univ Med Sci.; } 25 \text { (134):374-393 }\end{array}$ & 2016 \\
\hline 15 & $\begin{array}{l}\text { Bayati, R., Asadi-Gharneh, H. (2019). Study of Biochemical Compounds from Extract of Peel, } \\
\text { Seed and Fruit Juice of some Pomegranate Cultivars (Punicagranatum L.). Journal of Medici- } \\
\text { nal plants and By-product, 8(2), 133-141.doi: 10.22092/jmpb.2019.120491 }\end{array}$ & 2019 \\
\hline
\end{tabular}

\section{Discussion Table- III:}

As compared to the works in Table I \& II the works herein commences from 1971 while in the Occident from 1988; Govt of India from 1990 and by Bhattacharya (co-author) from 1997 for antimalaria and for anti-virus in 2004 (augmenting info). Medical collages \& Med Sc University are seen to be involved (apart individuals and insti- tutions as in Table I \& II). Therefore, we are of the considered view that pomegranate has surely been weighed as a therapeutic member in Persia \& also in present day Iran; that there is indeed scope for pan global inter-governmental work for global historiography of this fruit member.

\section{TABLE - IV Approved Ayurvedic Texts}

RJPP: https://escipub.com/research-journal-of-pharmacology-and-pharmacy/ 


\begin{tabular}{|c|c|c|}
\hline SL.No. & Name of The Books with Publication Details & Year \\
\hline 1. & $\begin{array}{l}\text { Rasendra Sara Samgraha of Sri Gopalkrishna: Commentary by: Pt. Girijadayalu Shastri, Pub- } \\
\text { lisher: Chowkhamba Sanskrit Series Office, Varanasi (India), } 4^{\text {th }} \text { Edition }-1952\end{array}$ & 1952 \\
\hline 2. & $\begin{array}{l}\text { Ashtanga Samgraha of Srimad Vagbhata Commentary by: Vaidyashri Govardhan Sharma } \\
\text { Chhangni, Published by: Chowkhamba Sanskrit Series Office,Varanasi (India), Reprint Edi- } \\
\text { tion, } 1954\end{array}$ & 1954 \\
\hline 3. & $\begin{array}{l}\text { Yoga Ratnakara, Commentary by: Vd.shri Lakshmipati Shastri, Edited by : Shri Brahmashan- } \\
\text { kar Shastri Published by : Chowkhamba Sanskrit Series Office,Varanasi (India), Reprint Edi- } \\
\text { tion,-1955 }\end{array}$ & 1955 \\
\hline 4. & $\begin{array}{c}\text { Siddha Yoga Samgraha By: Vaidya Yadavji Trikamji Acharya,Published by :Shri Baidyanath } \\
\text { Ayurved Bhawan Ltd,Kolkata(India),Fifth Edition-1957 }\end{array}$ & 1957 \\
\hline 5. & $\begin{array}{l}\text { Sushruta Samhita of Maharshi Sushruta Commentary \& Edited by: Kj. Ambikadatta Shastri } \\
\text { Published by: Chowkhamba Sanskrit Series Ofice,Varanasi (India), First Edition-1959 }\end{array}$ & 1959 \\
\hline 6. & $\begin{array}{l}\text { Rasaratna Samuchchaya of Sri Vagbhatachrya Commentary by: Kaviraj Ambikadatta Shastri, } \\
\text { Published by: Chowkhamba Sanskrit Series Office,Varanasi(India),Third Edition,-1961 }\end{array}$ & 1961 \\
\hline 7. & $\begin{array}{l}\text { Rasaratna Samuchchaya of Sri Vagbhatachrya Commentary by: Kaviraj Ambikadatta Shastri, } \\
\text { Published by: Chowkhamba Sanskrit Series Office,Varanasi (India), Third Edition,-1961 }\end{array}$ & 1962 \\
\hline 8. & $\begin{array}{c}\text { Ayurveda Prakasha of Acharya Sri Madhava Cmmentary by: Vaidya Vachaspati Shri Gulraj } \\
\text { Sharma Mishra, Publisher: Chaukhamba Bharati Academy,Varanasi (India), First Edition-1962 } \\
\text {,Reprint-1999 }\end{array}$ & $\begin{array}{c}19628 \\
1999\end{array}$ \\
\hline 9. & $\begin{array}{c}\text { Rasatantra Sara va Siddha Prayoga Samgraha By Swami Shri Krishnanandaji Maharaj Pub- } \\
\text { lisher: Krishnagopal Ayurved Bhawan,Kaleda(Ajmer),First Edition,-1966 }\end{array}$ & 1999 \\
\hline 10. & $\begin{array}{c}\text { Gada Nigraha of Srivaidya Sodhala, Commentary by: Indradeva Tripathy, Edited by Gan- } \\
\text { gasahay Pandey Published by: Chowkhamba Sanskrit Sansthan, Varanasi (India), Reprint Edi- } \\
\text { tion-1969 }\end{array}$ & 1969 \\
\hline 11. & $\begin{array}{l}\text { Bhava Prakasha: Commentary by: Dr.Krishnachandra Chunekar et al, Edited by: Dr. Gan- } \\
\text { gasahay Pandey Published by: Chaukhamba Bharati Academy, Varanasi(India) First Edition- } \\
\text { 1969,Reprint-1999 }\end{array}$ & 1969 \\
\hline 12. & $\begin{array}{l}\text { Bhaishajya Ratnavali: By: Shri Gobindadas, Commentary by: Kj. Ambikadatta Shastri Edited } \\
\text { by: Shri Rajeshwardatta Shastri Published by: Chowkhamba Sanskrit Sansthan, Varanasi (In- } \\
\text { dia), Fifth Edition,1978 }\end{array}$ & 1978 \\
\hline 13. & $\begin{array}{c}\text { Sahasrayoga: Translated by Dr. Ramnivas Sharma et al, Publisher: Dakshin Prakashan, Hy- } \\
\text { derabad-2(India), First Edition (Hindi)- } 1989\end{array}$ & 1989 \\
\hline 14. & $\begin{array}{l}\text { Sharangadhara Samhita: Commentary by: Dr. Brahmananda Tripathy, Pulished by: Chau- } \\
\text { khamba Surbharati Prakashan,Varanasi (India) First Edition- } 1990\end{array}$ & 1990 \\
\hline 15. & $\begin{array}{c}\text { Ayurveda Sara Samgraha, } 19^{\mathrm{TH}} \text { Edition, -1997 Shri Ramrakshak Pathak, Published by: Shri } \\
\text { Baidyanath Ayurved Bhawan Ltd, Nagpur, (India) }\end{array}$ & 1997 \\
\hline 16. & $\begin{array}{c}\text { Bhava Prakasha: Commentary by: Dr.Krishnachandra Chunekar et al, Edited by: Dr. Gan- } \\
\text { gasahay Pandey Published by: Chaukhamba Bharati Academy, Varanasi (India) First Edition- } \\
\text { 1969,Reprint-1999 }\end{array}$ & 1999 \\
\hline 17. & $\begin{array}{c}\text { Brihat Nighantu Ratnakar of Lala Shaligramji Vaishya: Khemraj Shrikrishnadas pulica- } \\
\text { tions,Kalyan, Mumbai } \\
\text { First Edition-1999 }\end{array}$ & 1999 \\
\hline 18. & $\begin{array}{l}\text { Ayurveda Samgraha: By Kj. Debendranath Sengupta et al Published by Dipayan, Kalkata (In- } \\
\qquad \text { dia) } \\
\text { First Dipayan Edition (Bengali),1999 }\end{array}$ & 1999 \\
\hline 19. & $\begin{array}{l}\text { Charaka Samhita of Agnivesha: Commentary by: Pt.Kashinath Shastri et al Editorial Board: } \\
\text { Pt. Rajeswardatta Shastir et al Published by : Chowkhamba Sanskrit Sansthan,Varanasi (In- } \\
\qquad \text { dia), } 5^{\text {th }} \text { Edition, } 2001\end{array}$ & 2001 \\
\hline 20. & $\begin{array}{l}\text { Ashtanga Hridaya of Srimad Vagbhata Commentary by: Dr. Brahmananda Tripathy, Pub- } \\
\text { lished by: Chowkhamba Sanskrit Pratisthan, Varanasi (India), 9th Edition-2002 }\end{array}$ & 2002 \\
\hline 21. & $\begin{array}{l}\text { The Ayurvedic Formulary of India Part-I vol-VI, } 2^{\text {nd }} \text { Edition } 2003 \text { The Controller of publica- } \\
\text { tions, Govt. of India, Civil lines, New Delhi }\end{array}$ & 2003 \\
\hline
\end{tabular}




\begin{tabular}{|c|c|c|}
\hline 22. & $\begin{array}{c}\text { Bangasena Samhita of Vangasen,Commentary by: Pt.Harihar Prasad Tri Pathy, Publisher: } \\
\text { Chowkhamba Sanskrit Series Office,Varanasi (India), First Edition-2004 }\end{array}$ & 2004 \\
\hline 23. & $\begin{array}{c}\text { Rasa Yoga Sagara: Commentary by: Vaidya Pandit Hariprapanna Sharma, Chowkhamba } \\
\text { Krishnadas Academy, Varanasi (India), Reprint Edition-2004 }\end{array}$ & 2004 \\
\hline 24. & $\begin{array}{c}\text { Arka Prakasha of Lankapaty Ravana: Commentary by: Indradeva Tripathy, Published by: } \\
\text { Chowkhamba Krishnadas Academy, Varanasi (India), 2 } 2^{\text {nd }} \text { Edition,2006 }\end{array}$ & 2006 \\
\hline 25. & $\begin{array}{c}\text { The Ayurvedic Pharmacopoeia of India Part-I vol-VI, First Edition -2008 The Controller of } \\
\text { publications, Govt. of India, Civil lines, New Delhi }\end{array}$ & 2008 \\
\hline 26. & $\begin{array}{c}\text { Chakra Datta of Shi Chakrapani Datta, Commentary by: Vaidya Ravidatta Shastri, Pulished } \\
\text { by: Chaukhamba Surbharati Prakashan,Varanasi (India), Reprint Edition-2012 }\end{array}$ & 2012 \\
\hline
\end{tabular}

NOTE: Ref No 6 gives a select list of Palm Leaf Manuscripts as are preserved in the Odisa State Museum, Bhubaneswar. Digital copies available. Indian Journal of History of Science, Indian National Science Academy, Vol. 49.3, pp.

294-97.

\section{Discussion - Table IV}

Table-IV members all have umbilicals to periods like 2000 - to - 5000yrs before present. The translation-based recessions and resensions of that \& those hoary Classical Ayurvedic treatiese are noted from 1952 (India $1^{\text {st }} 5 y$ plan). In these classical medicinal texts, the punica is mentioned aside all other medicinal herbs (it is not the sole focus). Moreover, the fruit used in the
Persian and Occident studies be the juice variety. Whereas, in the Ayurveda classical Texts (Table-iv) the member as in Fig-1 \& 2 be the sole active pharmaceutical ingredient (API). Pan globally it is exclusive \& novel. Hence, we indulgently term this API as Punica Ayurvedica. India obtained independence in 1948. Mahatma Gandhi assiduously used only Ayurvedic medicaments (Indian national school of medicine).

Table - V

\begin{tabular}{|c|c|c|}
\hline SI No. & Theological Sources: Brief Statement & Debatable Datum \\
\hline 1 & $\begin{array}{l}\text { Judaism: Pomegranate in The HOLY Tanakh } \\
\text { https://outorah.org/p/5701/ }\end{array}$ & Pre Christ \\
\hline Remarks & \multicolumn{2}{|c|}{$\begin{array}{l}\text { By post fix 'ism' we do not mean any dogma nor anything low or luminal save \& except mere conven- } \\
\text { ience. }\end{array}$} \\
\hline 2 & \multicolumn{2}{|c|}{ Hindu: The Sanatan Texts are so very vast and myriad; mostly in Sanskrit lingua. } \\
\hline Remarks & $\begin{array}{c}\text { Sanatan (perennial) also include a vast repository of multi-disciplinary texts } \\
\text { of Vedic Vigyan (plural sciences). Sanskrit = self-gelling: highly technical } \\
\text { lingua not mastered by present author group is left out. Require inquest in } \\
\text { association with authorities versed in the art. }\end{array}$ & $\begin{array}{l}\text { 3000-to-1000yrs } \\
\text { pre to Christ. }\end{array}$ \\
\hline 3 & $\begin{array}{l}\text { Christianity: } 4 \text { (supposed) mentions in the Bible. } \\
\text { https://bible.knowing-jesus.com/topics/Pomegranates }\end{array}$ & $\begin{array}{l}\text { Between Charlming - } \\
\text { Renaissance } \\
\text { c. } 1400 \text { A.D. }-1700 \text { A.D. }\end{array}$ \\
\hline Remarks & \multicolumn{2}{|l|}{ Available as quotes } \\
\hline \multicolumn{3}{|c|}{ Ayurveda (plural health) texts have been mentioned as separate Table No IV } \\
\hline 4 & $\begin{array}{l}\text { Buddhism: (i) Associated with mind change of the live infant flesh-eating } \\
\text { demon god Hariti - all Buddha domains (ii) Choice wedding gift in China. } \\
\text { http://www.amazing-pomegranate-health-benefits.com/pomegranate-bud- } \\
\text { dhism.html }\end{array}$ & $7^{\text {th }}-11^{\text {th }}$ A.D. \\
\hline Remarks & \multicolumn{2}{|c|}{$\begin{array}{l}\text { Philosophy expounded by Buddha was Hinayana (lesser path) c. } 6^{\text {th }} \text { BC to c. } 6^{\text {th }} \text { A.D. No mention.No } \\
\text { Gods; No demi gods } \\
\text { All this noted in Mahayana literature ( } 7^{\text {th }}-11^{\text {th }} \text { A.D.); Mahayana (Great path). }\end{array}$} \\
\hline 5 & $\begin{array}{l}\text { Islam: The pomegranate (ar-Rumman in Arabic), is mentioned thrice in the } \\
\text { Qur'an. In the Qur'anic verse quoted to the right, pomegranates are men- } \\
\text { tioned as one of heavenly fruits. } \\
\text { https://aboutislam.net/muslim-issues/science-muslim-issues/plants-quran- } \\
\text { part-3-pomegranate/ }\end{array}$ & $7^{\text {th }}-17^{\text {th }}$ A.D. \\
\hline
\end{tabular}

RJPP: https://escipub.com/research-journal-of-pharmacology-and-pharmacy/ 
Deepak Bhattacharya et al., RJPP, 2020; 4:9

\begin{tabular}{|c|c|c|}
\hline Remarks & \multicolumn{2}{|l|}{ Muhammad to End of Moghul Empire (india). } \\
\hline 6 & $\begin{array}{l}\text { Unani Medicine (india): "Unnani Tibb" describes the use of Pomegranate. } \\
\text { Indo Islamic School of medicine (Under Govt of India). }\end{array}$ & C. $1600-1900$ A.D. \\
\hline Remarks & \multicolumn{2}{|l|}{ See Table - I No 27 \& Table II No 15.} \\
\hline 7 & $\begin{array}{c}\text { Naturopathy: Herb of the Month: Pomegranate } \\
\frac{12 / 2016}{\text { Brisbane Naturopaths \& Wellness Centre. }} \text { Brittps://brisbanenaturopaths.com.au/2016/12/04/2016125herb-of-the-month- } \\
\text { pomegranate/ }\end{array}$ & 2016 \\
\hline Remarks & \multicolumn{2}{|c|}{$\begin{array}{l}\text { Since all such ancient practices use whole herbs and that modern sciences have evidenced that whole } \\
\text { herbs when distilled; refined; fractionated and only the most potent fractions are used drug-dose thera- } \\
\text { peutics take a sea change. However, whole use schools have their good counter arguments in place } \\
\text { and hence such practice gets to be called 'Naturopathy" i.e., treatment with items of nature natural. } \\
\text { Govt of india recognises 'naturopathy'. }\end{array}$} \\
\hline
\end{tabular}

\section{Discussion Table - V:}

Table $-\mathrm{V}$ is a micro representation of the idea that pomegranate had been the cynosure of various theo-philosophical societies, groups, guilds and related bodies in various parts of the world in various times in relation to good health. Logically these be the then therapeutics. Our hidden agenda is to subtly emphasise the historical fact that pomegranate was always considered also super safe. Tried a connect with human heritage. We only emphasis that vis-a-vis viremia our points among others are (i) seeds are contra (ii) rest of the fruit anti-virus- no wastes (iii) evidence-based studies indicate as anti-SARS sub spp wishfully included (iv) punica is the focus in all our cited manuscripts (v) Punica Ayurvedica is unknown outside india.

\section{Ayurvedic Punica's (Rind)}

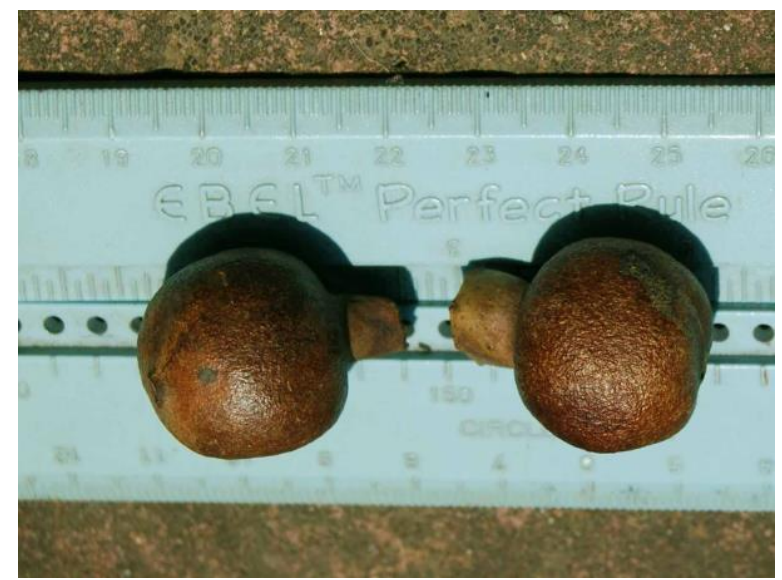

Fig-1: Classical indo Ayurvedic API - The Dalimba (P Granatum).

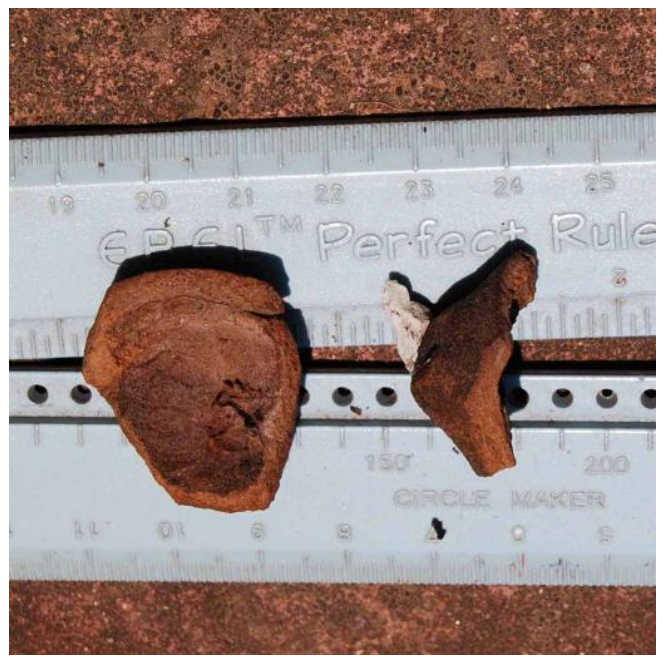

Fig -2 : its thick rind. Either to scale. Best specimen. Highest yield of drug moiety from rind

RJPP: https://escipub.com/research-journal-of-pharmacology-and-pharmacy/ 


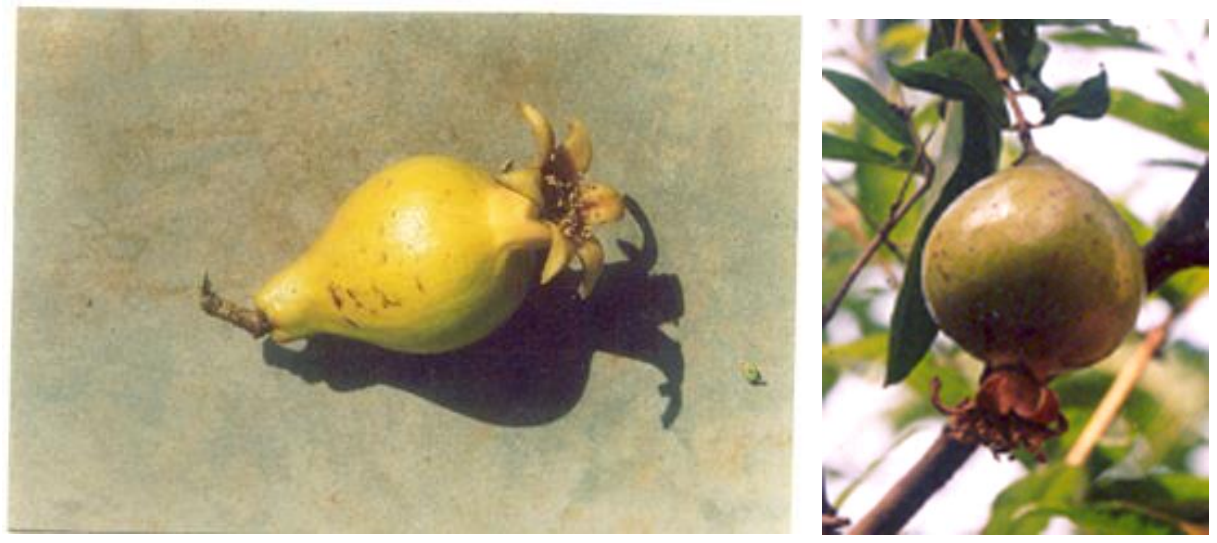

Fig-3 \& 4: are examples of atypical sub variety of Punica Ayurvedica.

The classical indo Ayurvedic member (Fig-1 \& 2) has no juice, no other confounding and or confabulating and or any other extra moiety excepting Potassium as an anomer. Its rind is thick; mini seeds; little aril; such rindlcarp is used only; on drying in airlsun becomes bone dry, stone hard; brown-amber colour; fine mesh powder of excellent bulk density. Its seeds have opposite effect $\&$ hence are discarded. And whereas, the commercial punica is well known to have other compounds; a leathery rindlcarp that is also thin and degenerates to black when airlsun dried. In the traditional texts the classical indo Ayurvedic punica (Punica Ayurvedika ?) is noted to be used in ' $n$ ' number of formulations; clinico-patho indications; ways and means save \& except fever; angina pectoris; and or swasa-kassa (COPD). Covid-19 becaused COPD \& angina pectoris onset heralds' grave prognosis i.e., 'end of life stage' ${ }^{[10-13]}$. To arrest such sad \& disastrous clinical situation every wherewithal however small or simple should be explored. There are no alternatives. ICAR has the largest stockpile of punica cum related wherewithal for ready deployment (supporting info). Indian private nationals \& entities jointly \& severally with Govt of India have invested huge sums of personal \& public money for punica orchards; commerce; fruit \& rind extraction; processing; packaging; etc., (SAARC nations included). Yet the rind's powder as a whole nor its extract has ever been utilised during pressing socio-national cum economic existential crisis viz. Covid-19. Hence, we break ice \& present formulations in Tablet \& Capsule. Being fully diabetes compliant. Seeds discarded full; aril selectively. Toxicity on Dermal Fibroblasts ${ }^{[14,15]}$; on MRC- 5 cells ${ }^{[16]}$; Selectivity Index [17]; Brain Malaria ${ }^{[18]}$; Anti-inflammation [19]; adjuvant role with Choloroquin ${ }^{[20,21]}$, etc., studies have indicated 'complete nontoxic and high safety'. Moreover; anti-virus efficacy has been reported in $2004^{[22]}$ through to 2020 [23]. No other tropico-deciduous yearlong fruiting member has so thoroughly been evidence based studied by acknowledged teams of experts from nations across over the last 30year period. "Punica combats covid". Active pharmaceutical moiety being Ellagic acid (gallagic group), the virion and the drug moiety being enantiomers. Antagoniostic.

\section{Commercial Juice Grade Punica}

Save \& except the classical Ayurvedic punica the world has a very large variety of the cultivar ${ }^{[24]}$ and genetic diversity ${ }^{[25]}$. The juice yield varies in $\mathrm{m} / \mathrm{lper} \mathrm{Kg}$ of pulp, so do the taste and the drug moiety \& other biochem content. Irrespective the juice remains tasty; physiologically useful; anabolic. We use (i) the classical Ay punica for tablet \& capsule (ii) the commercial (leathery-large) juice grade punica for formulations in suspension forms. Suspensions being fully compliant even for acutely morbid; convalescence patients; mother \& child; geriatric; catabolic; anabolic; sportsmen; anti-fatigue; general; and as pseudo psycho-somatic tonic. Suspensions being not suitable in status diabetes. Only seed is discarded. Aril \& rind \& internal musageous materials \& tissues (all) are pulped-squeeze extracted for they contain identical drug moieties.

\section{Stabilisation}

Punic juice is by nature stable at RT. Suspensi- 
ons need to be stabilised for attaining shelf life and for transit handling vortexes. For this we incorporate standard safe well accepted Ayurvedic \& Allopathic \& herbal \& soft drink making methods.

\section{Extraction, Purification \& Fractionation As- pects}

For the Commercial-fruit juice industry specific use there are a number of methods developed during the period 30yrs pre to present apart Sreeram's [26] and Reddy's methods [27]. All are relied upon.

For extraction from rind, we adhere to Del Agili's [28] Jean Barnard [29] and team's methods, wherein Bhattacharya (co-author) is a member for these were done exclusively for pathologytherapeutics. Let the family welfare \& health care providing stake holders subsume all these wholesomely.

\section{The Formulations}

Capsule making:

Can be handmade - home made. About to ripe stage fruit (choloroplast); cut, discard aril \& seeds. Seeds have opposite moiety. Aril is musgenous, less yield, hygroscopic, pro-mycotic; tends to clump-assist degeneration- not suitable for capsulation (for tablet ok for it imparts binding property, specially finger rolled pills as in Ayurveda along with anti-mycotic \& sporofic asafoetida 1\%). The rindlcarp on air or sun expouser (3-5days) become bone dry \& stone hard; splits on thrashing turning to fine mesh powder of yellow-brown colour. The deeper the tone higher be the moiety yield. Fill in 00 capsule @ 400-500mg. Ready to use. In limited free use as AVIR (anti-virus india research), Red Cross Charitable Clinic.

Tablet making:

Finger rolled: Carp \& aril powder + high pKa value compatible binder; 250mg per pill bears shipment vagaries well. Low compression force is best. Binder $=5$ to $10 \%$ Diospyros MelanoxyIon acts as glue cum synergicladjuvant moiety = ideal best. Short shelf.

Machine Pressed: High kNf $(1 \mathrm{~kg}$ movement @1mt per sec per sec) results in coupling of acid + tannin moieties $=$ new compound formation and or degeneration; liquefaction (early decay onset); etc. High kNf not advisable. Binder \& or coat as in above finger rolled or any from conventional pharmacy.

Nano Tech: Purified fractionated (sans seed). Whole punic has numerous constituents which all can be embedded in a novel tablet using Nano technology [30]. Retard delivery - gut stage specific. Most Broad spectrum. Superb results.

Dose: For CoV-2 spp. Anecdotally arrived at. Anabolic normal adolescent to normal Adult 30 to $60 \mathrm{Kg}$. Else, consult family physician.

Prophylaxis suggestive: 1 cap or Tablet once daily (OD) every $3^{\text {rd }}$ day; + citrated drinks. $<10 y r s$ $1 / 2$ amount. Or as advised by Family physician. As clinically indicated (ACl).

Acute Viremia: 2 cap or Tablet at a time BD (bis die sumendum) or TID (ter die sumendum) for initial 48-72hrs (as clinically indicated) with water ad-libitum along with conventional medicaments. ACl.

Mild Viremia: 1 or 2 cap or Tablet at a time BD with water adlibitum along with conventional medicaments for 5-15 days with water adlibitum along with conventional medicaments + citrated drinks. ACl.

\section{Suspension}

Diabetic: Carplrind powder soaked 4-6hrs., in I V grade Normal saline or in de-ionised, demineralised, tripled distilled water or injection water; bag centrifuged; harvested and bottled. Diabetic complaint $100 \%$. Excellent shelf life $2 y r s$ almost. Crushing of seeds to be avoided. Addition of 10\% Diospyros Melanoxylon v/v filtered whole extract imparts wider spectrum. Co-benefits: excellent for appetite; hepatocytes; gut persistalsis; hematinic and adipose brown or white; menarch women lower abdomen architecture \& reproductive organs performance. Preservatives not called for (least effective). Lower concentration = longer shelf.

Lyophylised: Lyophylised powder of a concentrate of the above can be prepared via tray system on large scale for reconstitution and use on desired volume basis. Light, fluffy and ready mixable; colloidal and all oils and enzymes preserved which all can be brought back to 
freshness on reconstitution. Complete reduction of gas bubbles. $100 \%$ efficacy retention enabling cross continent transhipment; armed forces destinations. Liquor admixable. Peerless.

Non Diabetic: Whole fruit along with Carplrind \& aril all fresh \& wet (sans seed); dip \& dunk washed; rinsed well ( $\&$ or dry air blast dried at $0^{\circ} \mathrm{C}$ ); slow cold pressed (any cultivar/sub spp.) + as optional whole Mohula (madhuca indica) concentrate $5 \% \mathrm{w} / \mathrm{v}$ or mohula wine $5 \% \mathrm{v} / \mathrm{v}$ or any type of country wine same vol; + Clove extract $1-5 \%$ optional (excellent up-regulator for de-virusing of the fossa \& epiglottis); sterile fructose $5 \%$ (or sterile gaggery or Ayurvedic sterile Nabata 5\% w/v (see sterilisation); All admixed; slow homogenised 30minutes. All process @ 2$4^{\circ} \mathrm{C}$; $<$ Rh $80 \%$ (ambient room). Addition of $10 \%$ Diospyros Melanoxylon v/v filtered whole extract imparts wider spectrum cum lingering taste $=$ release of digestive saliva \& pancreatic amylase. $\mathrm{Ph}-<4.4$. No seed crushing.

Geriatric (winter): Geriatric stage is a near continuous auto systemic inflammation stage. In winter temperature adjustment is more impaired due to week vessels which become leaky more and atopic hemodynamics. This is age related and height related vasculitis \& co-morbidity. Apart this there are other co-morbidities viz., IBS; sleepless; restless; listless; constipation; indigestion; epigastritis; spastic motion; atopic heart beats; psycho depression (mostly pseudo); idiopathic dermal itching, erythema, adipsialhypodipsia, dysphagia; UTI \&/or incontinence; etc. FORMULATION: whole juice $70 \%$ + Madhuca indica $15 \%$ + Raisin extract 10\% + ethanol $5 \%$.

Geriatric (summer):

FORMULATION: whole juice $70 \%$ + Madhuca indica $10 \%+$ Dates extract $10 \%+$ Orange or lemon $10 \%$. + ORS (daily limit $5 \mathrm{mg}$ ).

Constipation:

Normally in the semi-arid and arid geographic regions constipation is writ large.

FORMULATION: above on dates \& over ripe peach porridge for non-diabetes. lialukhudalkhai porridge for diabetes.

Bowl non-forming Individuals: geriatric stage is also associated with atypical - asyclic bowl formation failure. These forces non-charity fasting with psycho-somatic consequences.

FORMULATION: (a) Any of the formulations + (b) green banana porridge + (c) gram flour dumplings (Besan) + \&lor tapioca. B, C, D being cooked. Option: boiled potatoes \&/or eggs. Psycho Somatic Conditions (placebo): During work life period numerous medicaments are adhered too to enable fast forward alert \& agile attitude. On retirement an abrupt situation of 'no need' arises leading to mood swings. This apart there are ' $n$ ' number of clinic pathological, mental, professional, age related situations and conditions whence the human mind suffers median \& long period auto psycho - somatic syndromes; apart mood swings. A pleasant placebo be the medicament of choice. Any of our formulations can be advised by the family physician as a 'placibo'; all sex; all age groups.

Co-benefits: excellent for appetite; hepatocytes; gut persistalsis; hematinic and adipose brown or white. NOTE: seeds contain growth \& catalytic factors which up-regulate systemic inter molecule-actions specially during still storage (with the suspended enzymes \& essential or non-oils resulting in compounding, precipitations \& decay).

Spray Dried: A spray dried powder of a concentrate of the above can be prepared via large slow rotating drum dryers (milk powder type) of $40^{\circ} \mathrm{C}$ at $27 \% \mathrm{Rh} ; 700-800 \mathrm{hPa}$ room pressure; $30^{\circ} \mathrm{C}$ ambient room RT on large scale for reconstitution and use on desired volume basis. Light, crystalline, free flowing, ready mixable. $90 \%$ efficacy retention enabling large vol variable tin, poly packaging; large scale consumption, and cross continent transhipment.

Pectic enzymes: Is generally advised \& adhered to for attaining translucency (cloud effect reduction) [31] pre-final seal. Our view is that this is not future perfect. Pectic enzymes are catabolic; catalytic; high affinity for basal lamina; oncogenesis; reactive; deleterious for gall bladder and fallopian; not supported by gray haired drug designers or family physicians.

Colorants: Romantic purple-pink being the colour of the juice no additives envisaged. 
Preservatives: Ellagic acid \& Ellagitanins (gallagic group \& anthocynins) severally or jointly have excellent to peerless keeping qualities upto $\mathrm{Ph} 4$. Solid or suspensions.

Citric acids are contra indicated (shall because cement formation on vessel/container wall \& granules). Note: auto formed granules are rock solid also beget altered chemistry.

Dose: For CoV-2 spp. Anecdotally arrived at. Anabolic normal adolescent to normal Adult 30to $60 \mathrm{Kg}$. Else, consult family physician.

A mouthful, swirl, gurgle \& gulp $1 / 2$ twice as per individual preference. BD @ 12 hr interval. 1/2 for child $<10 y$ rs. BD $=$ Or sip - swirl-gurgle \& gulp TDS.

Container: Best is silliconised sterile glass bottles with seal caps and the juice being sealed with nitrogen (inert gas). PET bottles de-gas over long (antimony formation \& trace toxins) specially with catalytic materials like enzymes; acids. However, for periods such as 6 months and specially for cool shipments and in-fridge keeping consumable juices PET containers are OK (economic).

AVICo: Upper respiratory tracts mostly get effected by virus. $90 \%$ of the virions get physically trapped in the epiglottis - the $1^{\text {st }}$ physical natural barrier). CoV-2 has a long life, is tenacious, remains in the fossa and hence $>10 \%$ pass into the lungs by \& by. Therefore, an Anti-Virus Chocolate (AVICo); and AVA i.e., a paste (ahalia) can be prepared as follows. Aril paste $50 \%+$ condensed milk + Madhuca indica paste + processed tobacco leaf + coffee, etc., + sugar as required. Measure $\mathrm{v} / \mathrm{v}$ or $\mathrm{w} / \mathrm{w}$. It will be of special use for the infant, child, the geriatric group and or by the fast forward executive. Multi moiety prophylaxis. Natural physio compatible. Nonconfounding nor confabulating with life style medicaments.

Sterilisation: Whole fruit crushing and or use of raw part sun dried parts \& parcels also transports pathogens; effluxes pathologic moieties; pores \& cysts of bio-active zoonotic and phyto parasitic members. All these contribute to product degeneration and or to up-regulating pathologies post ingestion = Clinical headache. Some with delayed mechanism (in vivo incubation and or due dormantlactive-incubation-gestation periods). Hence, we recommend Gamma irradiation @ 20kilo gray for 1-2 hrs. This shall sterilise to pharma grade. The Govt. Of India has set up and has given licence to many a private entity to assist the herbal industry \& research with such objectives. Heat \&lor autoclave sterilisation also may be considered @200 $\mathrm{C}$ for $1 \mathrm{hr}$.

Special Note: Sepsis, malariasis \& cancer present near similar (clinically confounding \& perplexing) very high order of systemic spiralling inflammation (also SARS, MERS \& Covid). Pomegranate juice has very effective anti-oxidant and above all anti-inflammatory efficacy even in severe malariasis [32]; immensely compatible with paracetamol; on the ailing and or the geriatric or convalescent physiology (clinical observation \& Blood count methods/pathological tests). Therefore, administering such oral food along with $\mathrm{Pa}$ racetamol (250-450mg per day as clinically indicated i.e., sub clinical dose) will lead to precipitous wane of myalgia (become afebrile). Inflammation \& return to normal of the WBCs can be viewed via field microscope as in Ref 32 . Very useful shall it be also in seasonal viremias.

\section{Hematological Aspect}

Squeezing whole pomegranate fruit yields copious ellagitannins (highest among fruit juices). Such tannins are largest polyphenol compounds. Includes ellagitanins \& gallagic group which all are APIs having agro-met \& or sub spp., based variability. The gross yield of such APIs being greater from the crushed/squeezed rind and mesocarp (harsh taste) of the fruit than from the fresh aril (sweet taste). This scarlet-violet tasty juice has been used for centuries since ancient culture periods for 'medicinal purposes' [33] We presume haematological issues as also included in such over-arching historical \& cultural averment/s.

We are of the opinion that ellagic i.e., gallagic group has more specificity for RNA virions while ellagitanins for all stages of the anthropomorph malariasis. In the gastric chamber either forms the other \& vice-versa. Jointly or severally either also conjugate to form metal-ion complexes and 
trigger intrinsic coagulation [34]. Coagulation is easy manageable [35]; is not an issue. This is because the gallagics are 300-325 Dalton, and the anthocynins (1000-1200 Dalton) are stable, slow - to - non-reactive, good paramagnetic property, process scavengers, have salutary effect affinity for smooth \& involuntary laminas, etc. The virion $\&$ the acid-tanins are all enantiomers (compound-compound affinity interaction). The metallo-protienase are biogenic \& reversible ( $\mathrm{Hb}+$ gallagic+\{pro\}thrombin). This is precisely why we have advocated formulations for geriatric stages and in vasculities. $12 \mathrm{hrs}$ post bellyful ingestion of such juice blood donation shall be of fruition for the warm whole blood handling, transit, shelving $\&$ pheresis processes apart for the receiver as well yeomanly.

Cancer \& Punica: We intend to underline that Punica rind powder@ $050 \mathrm{mg}$ in 00 caps are in extensive use (as non-medicine) in all forms and stages of malignancy at MRC-Vedic Anti-Cancer as part of 'social contract' and also in a rural Red Cross mini clinic since $1998{ }^{\text {[36] }}$ and for cancer nursing \& in end of life stage support ${ }^{[37]}$.

\section{Multi-Drug Therapy Compatibility}

Koraput is malaria drug resistant \& mutant variety core endemic hub of India. CQ is considered as 'dud' therein. In ref No. 21 it has been indicated as to how Bhattacharya \& Pradhan along with the officials of the Collector cum Dist Magistrate; nurses (mostly Christian missionary) had re-ennobled (such dud) CQ by co-administering with Punica Ayurvedica powderlin hand made cap form 'OMARIA-AVIR'. Bio-chemically in gastric \& all gut phases $C Q+$ Anthocynin = hydroxyquinone a new compound is formed that can hydrolyse back to constituent moieties and again re-form; long duration blood borne \& bioavailability (least systemic loss; no contra; no delayed side effect). All this being abundantly articulated in public since 2000 (BBC news, Table I, SI. No. 9). There is compound - compound interaction resulting in new (non-dimmer) physio compatible compound formation viz., HCQ; efficient uptake; longer blood life than $C Q$; down regulation of all side effects of $C Q$ (even loading bolus dose) due the scavenging cum anti- inflammation efficacy. CoV-2 alike malarial hemoparasite is a non-haem-lympho genic charge particle that has affinity for the WBCs and the cytokines. Hence, we are optimistic that concurrent use of pomegranate juice and its products (alongside all types of therapies) shall be very useful; more so in patients who all be immunized (future date).

\section{Medico Legal Aspects}

Allopathic drug discovery has historically been inspired by mother nature ${ }^{[38]}$. Hand making home making of food-based items are statutorily non-drugs. They be home remedies. Scientific evidence backed home remedies are just a logical step forward of the ancient 'very long period observation-based studies. In India's vast country side family inheritance-based Ayurveda practitioners provide the bulk of the macro-level health care in micro scales. They come under the classification of 'tiny' \& 'micro-industry' \& 'cottage industry' (all are hand to mouth- bare sustenance level self-employment efforts). Rural folks also repose greater faith on such school of medicine. Furthermore, internal (so called) medicine comprised of fruit parts and parcels are safe. Additionally, peer reviewed research documents evidenseth that Punica Granatum (dalim/bedana) based medicaments are non-toxic. Conventional medicines can also be made. Moreover, the Clause 32 (1), p.19. of the (indo) National Medical Commission Bill, 2019 (Bill No. 185-C of 2019; Passed by LOK SABHA, 29.07.2019); enjoins upon the Union and her constituent provinces to incorporate and empower "Community Health Providers" as the initial health service and health care ${ }^{[39]}$. Inter-alia this means that M Scs; Ph.Ds; Drug Discovery and NGO people who all have more than 1 decade of related community health care-social work are now (deemed licentiate as) "Community Health Providers". A anti-virus licensed product by name AZAD (same as AVIR) is noted to have been issued by Gujarat Govt vide No. GAl1546; M/s Durga Ay Pharmacy; \& GAl1531; $\mathrm{M} / \mathrm{s}$ Lincoln Pharma). Thus, there is precedence. Therefore, our considered view is that the formulations if done manually by hand at home they 
then do not attract any licensing requirements. Else, A re-reading of the law may be necessary. Discussion Cum Conclusion

We note 2 types of punica granatum (i) non-juice variety \& no sugarlfructose (ii) juice variety - has sugar \& fructose. The member as in Fig-1 \& 2 are non-juice variety, exclusively used in Ayurveda for therapeutics (geographical S E Asia). The indo Brahmins (scholarslerudite) \& the wellto-do among the non-Brahmin families plant this variety of the cultivar at entrance besides, apart using its flower for certain rituals (region specific). It is not an albino member nor is it wild. It is part of medicinal heritage. We suggest the name Punica Ayurvedica. From 2004 to 2020member Fig-1 \& 2 has been in slow flow continuous use in Bhubaneswar and specially in the Indian Red Cross Society's charitable dispensary cum clinic at Koraput, Odisa under banner AVIR: anti-virus india research \& licensed label AZAD [40,41] \& OMARIA (Orissa Malaria Research Indigenous Research Attempt) and as EAK, respectively. This proves its efficacy as anti-virus and as anti-malarial ${ }^{[42,43]}$. Pan global dominancy in raw material (fruit-Punica); 1.3 Billion census that is mostly joint or large family based \& culturally \& ethenically intently social (distancing is looked upon with disdain in India); low electronic coverage (lock down seriously debilitates economy); a huge pharmaceutical nationwide base (underutilised); nil purelmono punica formulations with a crying patho-clinical need; unlimited market \& enabled youth employment potential. Our objective herein is to discuss all such supporting aspects AND enumerate hand makeable, home makeable 'formulations'. Hinting at length the related historiography of the candidate source/s; in brief bio-mechanics; drug kinematics; pharmacognasy; formulation making; principles and practices; drug-dose idea; etc., opportunities for topical levity. Table I-V are not exhaustive.

In Iran (historical Persia; present day geographical middle east) scientific studies of the juice variety pomegranate was research published in 1971 followed by Europe 1988; USA 1989; India 1990 (limited by our search). SARS-CoV 2 is an
RNA particle. RNA particles of pre CoV-2's susceptibility against both the types of granatum well stands out in some light affirmatively as transpirations herein. Either can be used to make exclusive formulations and supplements; etc. Moreover, punica is pregnancy safe; hematinic; has Potassium as an anomer [see R-16]. Potassium moiety is very helpful in therapeutics, especially in Brain malaria; muscular atrophy; general acute morbidity and in convalescence. However, inspite of decades of such foundational work there are no formulations et.al., that an average house hold head may buy off shop. In the out, there is a crying need. Hence, we have given formulations and making techniques both by hand at home and with machines at factories. All covid carriers cured; dormant and or asymptomatic and their immediate close contacts shall benefit from such cottage industry and or industrialised products. The Father of the Indian Nation Mahatma Gandhi supported "production by the masses \& for the masses" [44]. He never used anything other than Ayurvedic medicaments ${ }^{[45]}$.

The press and the powers that be are only talking about 'vaccine'. Non are talking about (i) economic super safe, eco-friendly and employment creating oral drugs $\backslash$ medicaments (ii) the interest of the pharmacy community, its employment scenario; banking loan burden offset, etc., aspects (iii) the vital role that family physicians can play (iv) mining india's or Middle East's huge natural resource bank. Our formulations are frank and nascent effort towards "Fight Covid At Home" “Ghare Maro Covid". Appreciated world over [46].

\section{Acknowledgement:}

We have to thank ' $n$ ' number of people for we stand on their broad shoulders. This transaction is dedicated to all previous workers and their associates. With their silent approval and deemed assistance we "Combat Covid At Home" (Ghare Maro Covid). No Patents, No Copy rights shall be applied for. Open for exploitation in unlimited manner \& modes.

\section{REFERENCES}


[1] Why a pomegranate? British Medical Journal 2000; 321 doi: https://doi.org/10.1136/bmj.321.7 269.1153

[2] Personal Communication of Dr. J Sharma, Director, NRCP-ICAR.

[3] http://nrcpomegranate.icar.gov.in/

[4] https://www.iihr.res.in/

[5] Bhattacharya, et.al, 11-5-2020. COVID-2019: Indian Medicine Sources Drug Discovery Possibilities, Scholarly Community Encyclopedia, MDPI, https://encyclopedia.pub/1268

[6] 6-Bhattacharya Deepak, 2014. Select palm leaf manuscripts of Health Care Sciences, Indian Journal of History of Science, Indian National Science Academy, Vol. 49.3, pp. 294-97.

[7] Director, https://nrcpomegranate.icar.gov.in/Contact .

[8] Jorfi, Abdul Amir, 1994. 'Iran and India: Age old Friendship' by, India Quarterly - A Jor of International Affairs, Vol. 50 Issue 4, pp. 65-92. https://doi.org/10.1177/097492849405000404

[9] Vajpayee, Atal Bihari, 2001. India Greatly Values Its Relationship With Iran, Teheran Times, 10-42001, pp-Politics.

https://www.tehrantimes.com/news/61466/India-Greatly-Values-Its-Relationship-With-IranVajpayee \& (preceded by J L Nehru Memorial Museum Library) https://www.nationalheraldindia.com/international/iran-draws-inspirationfrom-jawaharlal-nehru-as-us-sanctions-loomover-ties-with-india (Both - PM of India).

[10] Bhattacharya, Deepak \& Unnati Bhattacharya, 2018. Anti Tumor Orient Experiment - ATOX, Indian Journal of Natural Sciences, Vol.8 / Issue 48, pp. $13996-14002$.

[11] https://www.academia.edu/31709894/M_R_C.pdf AND https://www.researchgate.net/publication/314229235 METASTASIS REVERSAL_CENTRE

[12] Behera Jagdish \& Deepak Bhattacharya, 4/2020. AVIR - Anti Virus India Research COVID-19: Drug Discovery Safe Sources, Indian Jor Of Natural Sciences, Vol.10 / Issue 59 / pp.18923 - 18929.

[13] Behera Jagdish \& Deepak Bhattacharya, 4/2020. Covid-19 Glossary, NIH-Figshare, https://figshare.com/articles/COVID_GLOSSARY/12091854

[14] Peatey, C. L., D. Leroy, D. L. Gardiner and K. R Tren-holme, 2012. "Anti-Malarial Drugs: How Effective Are They Against Plasmodium falciparum Gametocytes?" Malaria Journal, Vol. 11, p. 34. doi:10.1186/1475-2875-11-34

[15] Soh P N, et al. 2009. In Vitro And In Vivo Properties Of Ellagic Acid In Malaria Treatment,
Antimicrob Agents Chemotherapy. 2009;53(3):1100

1106.doi:10.1128/AAC.01175-08.

[16] Dell' Agli M, et.al., 2010. Ellagitannins of the fruit rind of pomegranate (Punica granatum) antagonize in vitro the host inflammatory response mechanisms involved in the onset of malaria. Malaria Journal, 2010;9:208. doi:10.1186/14752875-9-208.

[17] Lekana-Douki, Deepak Bhattacharya, et.al., International Journal of Clinical Medicine, 2012; 3(1):1-8. Doi:10.4236/ijcm. 2012.31001.

[18] Prato M, Giribaldi G. Matrix Metalloproteinase-9 and Hemozoin: Wedding Rings for Human Host and Pf Parasite in Complicated Malaria. Journal of Tropical Medicine. 2011;1-11. (special ref., p.6). doi:10.1155/2011/628438.

[19] Bhattacharya Deepak (2012) Relevance Of Economic Field Microscope In Remote Rural Regions For Concurrent Observation Of Malaria \& Inflammation, Advances In Infectious Diseases, Vol. 2, pp.13-18. doi:10.4236/aid.2012.21003.

[20] Deepak Bhattacharya, "Fight Malaria at Home: Therapeutic \& Prophylaxis Clinical Data," Asian Pacific Journal of Tropical Disease, Vol. 1, No. 2, 2011, pp. 142-149.

[21] Deepak Bhattacharya, 2017. Fight Malaria at Home: Ghare Maro Malaria Social Service to Drug Discovery - Bottom Up Model: A Review, Air Water Borne Diseases, 2017, Vol.6:1 DOI: 10.4172/2167-7719.1000135

[22] 22 - Bhattacharya D. Punica granatum's dermis indicates prophylaxis against malaria \& wide spectrum anti-viral property in human use. American Journal of Tropical Medicine \& Hygiene, Oct. 2004. Abstract No. 968, 171(4), 288.

http://www.ajtmh.org/content/71/4_suppl/225.full.pdf+html.

[23] https://figshare.com/account/home \{ Login: oddisilab1@dataone.in \& Password : KedarGouri123*).

[24] Sharma J. Ashis Maity, 2010. Fruit Vegitable \& Cereal Sciences and Biotechnology, 4 (spl issue 2), pp.56-76.

[25] Patil, P.G., Jamma, S.M., Singh, N.V. et al. 2020. Assessment of genetic diversity and population structure in pomegranate (Punica granatum L.) using hypervariable SSR markers. Physiol Mol Biol Plants. https://doi.org/10.1007/s12298-020-00825-y

[26] Seeram NP, et.al., 2008. Pomegranate juice and extracts provide similar levels of plasma and urinary ellagitannin metabolites in human subjects. Jor of Medicinal Food 2008, 11:390-394. ALSO SEE same 1st author, Jor of Nutr 2006,136: 
2481-2485 AND again Clin Chim Acta 2004, 348:63-68.

[27] Reddy, M.K., et.al., 2007. Antioxidant, antimalarial and antimicrobial activities of tannin-rich fractions, ellagitannins and phenolic acids from Punica granatum L. Planta Medica, 73, 461-467.

[28] Dell' Agli M, et.al., 2009. Antiplasmodial activity of Punica granatum L. fruit rind, Journal of Ethnopharmacology, Vol. No. 125 pp. 279-285. doi:10.1016/j.jep.2009.06.025

[29] Opcit. Ref No 17.

[30] Bhattacharya, Deepak, 2017. Nano Tech Tablet: A Concept. Novel Approaches in Drug Designing \& Development, Vol. 2(2): 555582.

[31] http://www.fao.org/3/a-au112e.pdf

[32] Opcit. Ref No 19.

[33] Longtin, R 2003 The Pomegranate: Nature's Power Fruit ? Journal of National Cancer Institute Vol.95:346-8.

[34] Paul E. Bock, K. R. Srinivasan, and Joseph D. Shore, 1981. Activation Of Intrinsic Blood Coagulation By Ellagic Acid: Insoluble Ellagic AcidMetal Ion Complexes Are The Activating Species, Biochemistry, Vol.20 (25), 7258-7266. DOI: 10.1021/bi00528a032

[35] (i)https://www.academia.edu/31560111/Effect_of_Plant_Extract_R_Sol_on_Blood (ii)https://www.researchgate.net/publication/313839561_R_-_Sol_Magic_Effect_on_Blood

[36] Collectorate of Korpaut, Official Letter dycolemkpt@nic.in (dt. 21-5-2020), Official Site: koraput.nic.in/new/right/section.htm

[37] Bhattacharya, Deepak, 2017. Nursing Defeats Cancer?, J Complement Med Alt Healthcare, Vol. 5 Issue 3 - November 2017. DOI:10.19080/ JOJNHC.2017.05.555662
[38] Ameh SJ, et.al., 2011. Medical Herbalism And Herbal Clinical Research: A Global Perspective. British Journal of Pharmaceutical Research. 1.4:99-123.

[39] https://www.nhp.gov.in/NHPfiles/185C_2019_LS_Eng.pdf

[40] The Samaja, Odia Daily, Koraput, Ed 27-3-2020, page-7. https://samajaepaper.in/indexnext.php?pagedate $=2020-3-27 \&$ edcode $=79 \&$ subcode $=79 \&$ mod $=1 \&$ pgnum $=1 \&$ type $=a$

[41] The Samaja, Odia Daily, Koraput, Ed 17-5-2020, page -7. https://samajaepaper.in/in dexnext.php ?pagedate $=2020-5-17 \&$ edcode $=79 \&$ subcode $=79 \&$ mod $=1 \&$ pgnum $=1 \&$ type $=a$

[42] Bhattacharya Deepak, et.al., 2013 Transmission Blocking of Year Round Resistant Malaria in Koraput (India) by OMARIA - A New Antimalarial Phytotherapy, British Journal of Pharmaceutical Research, Vol. 3, No. 1, pp. 54-77, 2013

[43] Badam Lalita, Annual Report 2002-03, National Institute of Virology, Pune, India, Screening of AVIR, Other Viruses, No.6-a, p.126.

[44] Indian Express, J Roy-Chowdhury, 01-10-2019. "....Gandhiji thought instead of concentrating on mass production, we need to concentrate on production by the masses, where jobs are created so that demand too could be created..." Dr. Satya Narayan Sahu, Gandhian thinker.

[45] Gandhi M K. An Autobiography (The story of my experiments with truth). 1st Ed. Navjivan Trust, Ahmedabad; 1927.

www.myweb.tiscali.co.uk/kenanderson/histemp/whitemansgrave.html.

[46] https://encyclopedia.pub/1490 